\title{
Should the Lion Eat Straw Like the Ox? Animal Ethics and the Predation Problem
}

\author{
Jozef Keulartz ${ }^{1,2}$
}

Accepted: 25 August 2016/Published online: 31 August 2016

(C) The Author(s) 2016. This article is published with open access at Springerlink.com

\begin{abstract}
Stephen Clark's article The Rights of Wild Things from 1979 was the starting point for the consideration in the animal ethics literature of the so-called 'predation problem'. Clark examines the response of David George Ritchie to Henry Stephens Salt, the first writer who has argued explicitly in favor of animal rights. Ritchie attempts to demonstrate-via reductio ad absurdum - that animals cannot have rights, because granting them rights would oblige us to protect prey animals against predators that wrongly violate their rights. This article navigates the reader through the debate sparked off by Clarke's article, with as final destination what I consider to be the best way to deal with the predation problem. I will successively discuss arguments against the predation reductio from Singer's utilitarian approach, Regan's deontological approach, Nussbaum's capability approach, and Donadson and Kymlicka's political theory of animal rights.
\end{abstract}

Keywords Predation problem - Utilitarianism - Rights theories · Capability approach $\cdot$ Political theory of animal rights

\section{Introduction}

Stephen Clark's article The Rights of Wild Things from 1979 was the starting point for the consideration in the animal ethics literature of the so-called 'predation problem' (Dorado 2015, 234). In this article, Clark examines the response of Scottish philosopher David George Ritchie (1853-1903) to Henry Stephens Salt (1851-1939), who is credited to be the first writer to have argued explicitly in favor

Jozef Keulartz

j.keulartz@science.ru.nl

1 Environmental Philosophy, Radboud University, Nijmegen, The Netherlands

2 Wageningen University, Wageningen, The Netherlands 
of animal rights. Ritchie attempts to demonstrate-via reductio ad absurdum-that animals cannot have rights, because granting them rights would oblige us to protect prey animals against predators that wrongly violate the victim's rights.

In our guardianship of the rights of animals, must we not protect the weak among them against the strong? Must we not put to death blackbirds and thrushes because they feed on worms, or (if capital punishment offends our humanitarianism) starve them slowly by permanent captivity and vegetarian diet? What becomes of the 'return to nature' if we must prevent the cat's nocturnal wanderings, lest she should wickedly slay a mouse? Are we not to vindicate the rights of the persecuted prey of the stronger? Or is our declaration of the rights of every creeping thing to remain a mere hypocritical formula to gratify pug-loving sentimentalists. (Ritchie 2002, 109-110)

Clark argues against this predation reductio; he rejects Ritchie's conclusion that, if non-human animals had rights, we should be obliged to defend them against predators This conclusion, Clark asserts, "either does not follow, follows in the abstract but not in practice, or is not absurd" (Clark 1979, 187).

This article navigates the reader through the debate sparked off by Clarke's article, with as final destination what I consider to be the best way to deal with the predation problem.

I will first argue that the utilitarian approach to the predation reductio is ultimately a dead end. Utilitarians can only avoid this reductio if they are prepared to reconsider their opinion of predation as an evil that must be eradicated (section "Utilitarianism").

As I will argue next, Tom Regan's rights-based approach to animal ethics offers a less gloomy picture of predation and provides a more solid way to escape the predation reductio than the consequentialist approach. According to Regan we have no duty to interfere with wildlife to prevent predation because members of both predator and prey species possess a certain 'competence' and are capable of 'using their natural abilities' to survive on their own in the wild. This recourse to the notion of 'competence' could open an avenue for a more balanced view of the predatorprey relationship, in which predator and prey are no longer seen respectively as invincible and defenseless (section "Rights Theories").

To explore this avenue, I then turn to Martha Nussbaum's capabilities approach that centers on the idea that a creature's well-being is dependent on its opportunities to realize some basic natural abilities or competences. However, the considerable conceptual gains that Nussbaum is able to achieve through the introduction of the species-specific norm of flourishing in the discussion of the predation problem are at least partly being undone by the way she compiles a catalogue of innate or 'basic' capabilities relevant to animal species (section "The Capabilities Approach").

I finally turn to Donaldson and Kymlicka's political theory of animal rights. There are important similarities between this theory and Nussbaum's capabilities approach. But there is also a distinct difference: whereas Nussbaum attaches considerable importance to species membership, Donaldson and Kymlicka focus on community membership, thus taking account of the sociopolitical context of animal justice. They succeed in making further headway on the road to a satisfactory 
solution of the predator problem. However, with their sovereignty model Donaldson and Kymlicka have taken a place-based approach with regard to wild animals that ultimately fails to take sufficient account of the scope and scale of the anthropogenic stress that is inflicted upon these animals during the current stage of the Anthropocene (section "Political Theory of Animal Rights").

\section{Utilitarianism}

In his article The Rights of Wild Things, Stephen Clark mentions an important argument that utilitarians usually put forward to avoid the predation reductio: that the evil of predation cannot be eliminated without introducing worse ones. "Caribou may be spared the pain of wolves, or Eskimos, but the consequent population explosion will lead to overgrazing, disease, famine, and a population crash" (id., 175).

This argument was introduced in 1973 by Peter Singer in his reply to David Rosinger who asked him if we have a moral responsibility to prevent predation. In answering this question, Singer makes a distinction between domestic pets such as cats and dogs, and wild animals, like the lion. With respect to carnivorous pets, Singer thinks it right to try to raise them on a special vegetarian diet. But as for wild animals, he claims to be fairly sure, "judging from man's past record of attempts to mold nature to his own aims, that we would be more likely to increase the net amount of animal suffering if we interfered with wildlife, than to decrease it... So, in practice, I would definitely say that wildlife should be left alone" (Singer 1973, cf. Singer 1975, 226). Although Singer cautions against interfering with ecosystems because he fears that doing so would cause more harm than good, as a matter of principle, he believes that "if, in some way, we could be reasonably certain that interfering with wildlife in a particular way would, in the long run, greatly reduce the amount of killing and suffering in the animal world, it would, I think, be right to interfere" (Singer 1973). ${ }^{1}$

In order to avoid what he has called a "conceptual absurdity"-that we risk to cause more suffering than we would prevent -, Steve Sapontzis has added a proviso to the presumption that we are morally obligated to prevent predation. He claims that we are only committed to stop predation "whenever doing so would not occasion as much or more suffering than it would prevent" (Sapontzis 1984, 31). Sapontzis contends that this reformulation still contains a substantive obligation: it would for instance oblige us to prevent our pets from being predators, something that is also endorsed by Singer. "It would also obligate us to begin exploring other ways in which we could reduce the suffering caused by predation without

\footnotetext{
${ }^{1}$ Fellow-consequentialist Aaron Simmons fully agrees with Singer that saving wild animals "on any large scale would have disastrous ecological consequences" (Simmons 2009, 26). He doesn't believe at all in measures to avoid these bad consequences such as feeding vegetarian diets to predators to prevent starvation, or feeding contraceptives to prey animals to curb overpopulation. If done on any large scale, such measures as proposed by environmental philosophers like Mark Sagoff (1984) would not counter but only compound serious ecological problems.
} 
occasioning as much or more suffering, e.g., in zoos, wildlife preserves, and other areas where we are already managing animals" (ibid.).

In a similar vein, Charles Fink has argued that it does not follow from the alleged fact that large-scale interventions in ecosystems would do more harm than good that we should do nothing at all. Fink accuses all those who take an all-or-nothing approach to the predation problem of black-and-white-thinking. He concludes that "it is not inherently absurd to suppose that there is an obligation to protect animals from natural predators, even if this obligation has limited practical application" (Fink 2005, 15).

That we run the risk to cause more harm than good is not the only reason why there can be no obligation to defend prey animals against their predators. Another reason, also mentioned by Stephen Clark, concerns the over-demanding nature of such a duty. Any realistic attempt to fulfill a duty to intervene in predation would inevitably be detrimental to our performance of other duties. Our possibilities for positive action are simply limited: "Most of us, not being wandering preachers, can be vegetarians quite easily. Some of us can be vegans. But very few of us can wholeheartedly devote ourselves to the defence of mice" (Clark 1979, 179/180; cf. Hadley 2006).

In connection to this second objection Sapontzis speaks about a "practical absurdity", and he is convinced that this objection is as easily to refute as the objection in the case of the conceptual absurdity. It may be true that we are unable to eliminate predation entirely; but this does not render the obligation to prevent predation meaningless. It can function as a moral ideal that we should work toward and try to approximate ever more closely: "Consequently, it is not practically absurd" (Sapontzis 1984, 32).

\section{Piecemeal Engineering}

So, the consensus among utilitarianists is that we should intervene in predator-prey relations whenever doing so would not cause more harm than good or be overly demanding and incur costs that significantly outweigh the benefits. In his article Policing Nature from 2003, Tyler Cowen identifies a number of policy measures that seem to meet these criteria. Cowen's starting point is that we are already inevitably intervening in nature in massive ways, through agriculture, fishing, industry, building, mining and, of course, through nature conservation. These policies obviously affect predators and prey animals differently. Cowen calls for attempts to shift nature's balance of power to the detriment of predators and to the benefit of their victims. We should, however, do so in a cautious and humble way, without upsetting nature's balance in intolerable fashion. "We should count negative impacts on carnivores as positive features of the human policy, rather than as negative features, as we usually do. Doing so would make us less likely to support the populations of various aggressive carnivores" (Cowen 2003, 174). In order to shift nature's balance of power in the desired manner, we should, at the very least, stop subsidizing the propagation of carnivores and limit or eliminate programs to protect endangered carnivores or prevent their extinction. We should make hunting strictures against killing carnivores less tight than those against killing 
non-carnivores, or perhaps remove them altogether. And we should be more willing to use carnivores than non-carnivores in laboratory experiments.

\section{The Balance of Nature and the Argument from Ignorance}

The utilitarian consensus that the way forward is to proceed in a piecemeal and small-scale manner is based on two interconnected assumptions: that de balance of nature is essentially good for animals, and that we are simply too ignorant to police nature without constantly running the risk to disturb this balance. Both these underlying assumptions have however increasingly come under attack during the past few years.

The claim that the balance of nature is on the overall good for animals has already been contested in a paper from 1995 by Yew-Kwang $\mathrm{Ng}$. But it took until the late $2000 \mathrm{~s}$ before this paper started to gain real traction (see e.g. Dawrst 2009; Horta 2010a, b; Tomasik 2015). In this paper entitled Towards Welfare Biology Ng argues, on the basis of evolutionary economics and population dynamics, that the natural equilibrium is something quite terrible because all species suffer enormously in this situation. This is due to the prevalence of the reproductive strategy know as 'r-selection', which consists in producing large numbers of offspring per reproductive cycle. The overwhelming majority of animals that follow this reproductive strategy, including fishes, amphibians and reptiles, die shortly after birth, from starvation or by being eaten alive by predators or parasites. But even the tiny minority of animals that follow the other important reproductive strategy know as 'K-selection' will experience their share of suffering and misery as well, because they often also have a large numbers of eggs or offspring, which will be wasted before they reach sexual maturity. $\mathrm{Ng}$ concludes that for animals in the wild, their pain and suffering vastly outweigh their pleasure and happiness, so the widely accepted idyllic view that the current balance of nature is overall good for animals is definitely false.

As a consequence of this analysis, $\mathrm{Ng}$ and his followers, suggest that we can increase the level of overall animal welfare by lowering the birth-rates and reducing

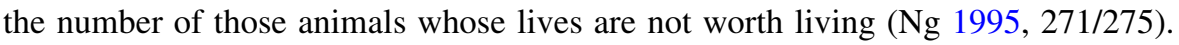
Consequently, Oscar Horta (2010b) considers species protection and biodiversity conservation as counterproductive to the promotion of animal welfare because this will increase rather than reduce the number of suffering animals. In a similar vein, Brian Tomasik has expressed the hope "that the animal-rights movement doesn't end up increasing support for wilderness preservation and human non-interference of all kinds" (Tomasik 2015, 148).

The second underlying claim, that our understanding is too limited to intervene in nature without causing serious ecological problems, is also far from unproblematic. As Clare Palmer has remarked, this argument from ignorance is not a resilient argument that interfering with wildlife is morally unacceptable in principle. Given the continuous development of sophisticated techniques such as vaccination, radio tracking, and wildlife contraception or sterilization, the argument from ignorance of the consequences will lose its validity in an increasing number of cases (Palmer 2010, 30, 2015, 205). 
Sue Donaldson and Will Kymlicka agree with Palmer that the argument from ignorance - they prefer to call it the 'fallibility argument' - seems to miss the target. This argument suggests that if we had the adequate tools and techniques at our disposal, we should start re-engineering the natural world to reduce suffering overall, thereby "turning nature into a well-managed zoo in which each animal has its own safe enclosure and guaranteed food source" (Donaldson and Kymlicka 2011, 164).

\section{Paradise Engineering}

To get a glimpse of this future re-engineered world, we might take a look at the work of David Pearce, a British philosopher and co-founder of Humanity+, the international transhumanist organization, whose purpose is the fundamental transformation of the human condition by developing and making widely available technologies to greatly enhance intellectual, physical, and psychological capacities, eventually building a 'Triple S' civilisation of Superhappiness, Superlongevity and Superintelligence. Pearce's ideas have inspired a strain of transhumanism called 'paradise engineering', an abolitionist program to achieve nothing less than the elimination of literally all suffering on the planet. He has outlined this program in his 1995 book-length internet manifesto The Hedonistic Imperative. In this manifesto, Pearce explains how technologies such as genetic engineering, nanotechnology, pharmacology, and neurosurgery could potentially converge to abolish suffering in all sentient life.

An important part of Pearce's abolitionist program aims to limit or eliminate predation, reducing the suffering of prey animals. He distinguishes two solutions to the 'barbarities' of predation: extinction and reprogramming. The first solution is "to use indiscriminate depot-contraception on carnivores and allow predators rapidly to die out, managing the resultant population effects on prey species via more selective forms of depot-contraception" (Pearce 2009, 6). The second solution concerns the genetic 'reprogramming' or otherwise behavioral conversion of aggressive carnivores into model citizens in our wildlife parks. "With suitable surveillance and computer control, whole communities of ex-predators could be discreetly guided in the norms of non-violent behaviour" (id., 8). Reprogramming and behavioral management can help ensure "the civilised survival of reformed lions and their relatives for human ecotourists to enjoy, if we so choose" (id., 10). ${ }^{2}$

Although Pearce's ideas about future technological developments are highly speculative, it nonetheless appears that utilitarians can no longer hide behind the argument from ignorance, but have to show their colors. They can choose to remain firmly committed to the view that predation is inherently bad, but then they can no longer escape from supporting some form of 'paradise engineering' by which nature

\footnotetext{
2 Just as David Pearce, White's Professor of Moral Philosophy Jeff McMahan has also embraced "the heretical conclusion that we have reason to desire the extinction of all carnivorous species" (McMahan 2010, 7). McMahan is likewise in favor of selecting carnivorous species for extinction and herbivorous species for survival, and would also support using genetic modification to gradually turn carnivorous species into herbivorous ones, "thereby fulfilling Isaiah's prophecy" (id., 2).
} 
will be turned into a well-managed zoo. Or they can choose to avoid this predation reductio, but then they will have to be prepared to reconsider their opinion of predation as an evil that must be eradicated.

\section{Rights Theories}

Tom Regan's rights-based approach to animal ethics offers a less gloomy picture of predation and provides a more solid way to escape the predation reductio than the utilitarian approach. Regan is also opposed to interference with nature to protect prey animals but not because doing so would cause more suffering than it would prevent. He argues that, although wild animals can certainly harm one another, they cannot violate one another's rights since, in contrast to human predators, nonhuman predators are not moral agents, but only moral patients; they do not possess the relevant capacities to be held morally responsible for their actions. So, we have no duty "to assist the sheep against the attack of the wolf, since the wolf neither can nor does violate anyone's rights" (Regan 1983, 285). With respect to animals in the wild, we have no positive duties of assistance but only negative duties of nonintervention and are not allowed to confine, torture or kill them. Wildlife managers, Regan claims, "should be principally concerned with letting animals be, keeping human predators out of their affairs, allowing these 'other nations' to carve out their own destiny" (id., 357).

Recently, Josh Milburn has convincingly given Regan's account a much-needed degree of nuance, arguing that the attribution of moral responsibility is not a question of 'either-or' but of 'less-or-more'. Milburn illustrates this point by the following example. A wolf killing a deer in isolated woodland does not violate the rights of the deer, but if the wolf's killing of the deer had taken place in a zoo, then there is some moral agent who is blameworthy in this situation, namely the zookeeper who placed the deer in the wolf's enclosure. This example shows that intervention in wildlife is only morally warranted "in those cases in which morally responsible agents can be found, and only to the degree that they can be found" (Milburn 2015, 288). ${ }^{3}$ Milburn concludes that the rights of prey do not generally necessitate intervention, because "the vast majority of predator-prey interactions are not linked to moral agents in an important way" (ibid.). As much as I appreciate the nuance that Milburn has introduced in animal rights theory, I don't share this conclusion because, as I will argue later, in this stage of the so-called 'Anthropocene', we humans are massively implicated in predator-prey relationships, for better or worse.

There are two kinds of objections that have been raised against Regan's rightsbased approach. The first kind of objections concerns the question if it is really morally relevant whether or not perpetrators are moral agents. The second kind of objections is no longer about the perpetrator but concerns its victim, and concerns the question whether it makes any difference if this victim is human or non-human.

\footnotetext{
3 In a similar vein Dale Jamieson has argued that moral evaluation is clearly in order when "predation is in some way affected by human agency, either because we have structured the encounter or because the predator is under our direct or indirect control" (Jamieson 2008, 186/7).
} 


\section{Lack of Moral Agency}

According to Steve Sapontzis, it is totally irrelevant for our obligation to prevent harm whether that harm is caused by a moral agent or not. He points out that we should separate our moral judgement of an act (as right or wrong) from our moral judgement of the actor (as innocent or culpable). Because we routinely hold parents responsible for preventing their 'innocent' young child from tormenting the cat, we also seem to have an obligation to stop the cat from killing birds (Sapontzis 1984, 27/8). ${ }^{4}$

Dale Jamieson (1990) has also criticized the way in which Regan tries to avoid the predation reductio by limiting the duty to render assistance to those animals in need that are the victim of moral agents, the only one's that can commit injustices. He illuminates the problematic character of this limitation by considering five hypothetical cases, in which a man will be crushed by a falling boulder unless I warn him. In the cases 1-3 a woman intentionally or inadvertently causes the boulder to roll toward the man; in the cases 4 and 5 the boulder is set in motion by a wolf and a landslide respectively. On the basis of Regan's theory, we don't have a duty of justice to warn the man in the cases 4 and 5, because neither wolfs nor landslides are moral agents and therefore cannot violate rights (see also Cowen 2003, 176). To avoid this highly counterintuitive conclusion Jamieson argues that we should supplement Regan's theory with a class of nondiscretionary duties that rest on some ground other than justice.

Regan has addressed Jamieson's criticism in his book Defending Animal Rights from 2001, and again, in almost identical terms, in his preface to the second edition of The Case for Animal Rights, published in 2004. Regan dismisses Jamieson's objection because a careful reading of the relevant passages would reveal that he has never maintained that we owe nothing to those in need who are not victims of injustice. He has only insisted that we do not owe anything to such individuals on the grounds of justice. There is nothing in the rights view, Regan contends, that prevents it from recognizing a general prima facie duty of beneficence that includes duties of assistance to those in need. "Thus there is nothing in my theory that would preclude recognizing a duty to warn the hiker about the free-falling boulder" (Regan 2001, 51).

Regan has acknowledged that he is "at least partly to blame" for Jamieson's misreading of his texts, because he does nowhere discuss other duties of assistance than those we have to victims of injustice, which he regards as a 'symptom of the incompleteness' of the theory developed in The Case. "In hindsight, I recognize that it would have been better had I said more about duties of assistance other than those owed to victims of injustice." (Regan 2004, xxvii). ${ }^{5}$

\footnotetext{
4 This example is quite similar to Milburn's example of the zookeeper who placed a deer in a wolf's enclosure.

5 However, as Regan has noted "most emphatically", the duty of beneficence has serious limitations. Notably, promoting some one's good should never go at the expense of another one's rights. "In this respect, the demands of justice always take precedence over the claims of beneficence" (ibid.).
} 


\section{Non-human Victims}

But adding duties of assistance that rest on some ground other than justice does not affect Regan's view that we have no duty to protect the sheep against the wolf. Why Regan holds on to this non-interventionist view will become clear as we shift the focus from predators to prey and look at the second important question raised by Regan's rights-based approach: whether it makes a difference if the victim is a human or non-human animal.

This question was posed by Carl Cohen in an article from 1997, in which he asks us to imagine two cases. In the first case a baby zebra is hunted to death by a lioness. If zebra's have a right to live, we ought to intervene, but we usually don't do so. In the second case the lioness is about to attack a human baby, and now we surely will intervene to stop the lioness. So, the question is: what accounts for the moral difference? Cohen's answer is that "animals cannot be the bearers of rights because the concept of rights is essentially human; it is rooted in, and has force within, a human moral world" (Cohen 1997, 95). The baby zebra has no right not to be slaughtered by the lioness, nor has the lioness the right to kill that baby zebra, simply because the concept of rights does not apply to animals.

In his article The Predation Argument from 2005, Charles Fink has also discussed the question why we should save a human life from predators but not an animal's life when doing so would be equally within our power, but he came to a conclusion diametrically opposed to Cohen's. It may be true, as Regan asserts, that wolves are not moral agents and thus cannot violate the rights of sheep, but it does not follow, Fink believes, that we have no obligation to assist the sheep against the attack of the wolf, considering what our reaction would be if a human being were attacked by a wolf. If we have a duty to protect all members of the moral community from harm, even if this harm is not caused by moral agents, then it would certainly seem to follow that, if sheep are members of the moral community, "there is an obligation to protect them from wolves, whether or not wolves violate their rights" (Fink 2005, 12).

In the preface of the second edition of The Case, Regan has also addressed Cohen's critical question concerning the moral difference between the case in which a wild animal is threatened by a predator and the case in which the predator is threatening a human child. In his view, we have a duty to save a human child from predators but no such duty with regard to wild animals. The crucial difference between the two cases is that members of both predator and prey species possess a certain 'competence' and are capable of 'using their natural abilities' to survive on their own in the wild, whereas young children do not have the same competence and are unable to survive, in the wild or in the home, without our assistance. We honor this competence of wild animals by just letting them be, even if their lives are threatened by predators. ${ }^{6}$

\footnotetext{
6 As Regan points out, that we have a prima facie duty to assist the child from the lion, does not oblige us to develop general policies "that seek to eradicate every predatory animal under the sun", let alone that we should develop such policies because predatory animals harm their prey (Regan 2004, xxxvii; cf. Donaldson and Kymlicka 2011, 165).
} 
This recourse to the notion of 'competence' could open an avenue for a more realistic solution of the predator problem. It allows for a more balanced view of the predator-prey relationship, in which predator and prey are no longer seen respectively as invincible and defenseless. To explore this avenue, I now turn to Martha Nussbaum's capabilities approach that, after all, centers on the idea that a creature's well-being is dependent on its opportunities to realize some basic natural abilities or competences.

\section{The Capabilities Approach}

The capability approach differs from the consequentialist approach and the rights approach in one very important respect. Nussbaum rejects the view, taken by both these approaches, that species membership itself is of no ethical and political significance at all. Following James Rachels, Nussbaum calls this view 'moral individualism'. 7 The capabilities approach, by contrast, does in fact attach moral significance to species membership as such. It is based on a species-specific norm of flourishing, that tells us what the appropriate benchmark is for judging whether a member of a species has decent opportunities for flourishing. The capabilities approach has also a strong affirmative character; it "treats animals as subjects and agents, not just as objects of compassion" (Nussbaum 2006, 351), and commits us to support the capabilities of all morally considerable beings, up to some minimum threshold level specific to each species.

However, the significant conceptual gains that Nussbaum would be able to achieve through the introduction of the species-specific norm of flourishing in the discussion of the predation problem are at least partly being undone by the way she compiles a catalogue of innate or 'basic' capabilities relevant to animal species (Keulartz 2016a). On the one hand, Nussbaum's account of animal capabilities seems to be distinctly pluralist. The capabilities approach is attentive to the fact that each species has a different form of life, and is capable of recognizing a wide range of types of animal dignity, and of the corresponding needs for flourishing. But on the other hand, Nussbaum suggests a one-size-fits-all approach, that has a distinctly anthropocentric character as it applies the same human yardstick to all animal species. ${ }^{8}$ Although she fully acknowledges that species-specific entitlements of animals are based upon their various characteristic forms of life and flourishing, she nonetheless wants to use the existing list of human core capabilities "to map out, in a highly tentative and general way, some basic political principles that can guide law and public policy in dealing with animals" (id, 392). ${ }^{9}$

\footnotetext{
7 According to Rachels, "moral individualism is a thesis about the justification of judgments concerning how individuals may be treated. The basic idea is that how an individual may be treated is determined, not by considering his group memberships, but by considering his own particular characteristics" (Rachels 1990, 173).

8 In Women and Human Development, Nussbaum argues that the central capabilities "are held to have value in themselves, in making the life that includes them fully human" (emphasis added) (2000, 74).

9 In her review of Steven Wise's book Rattling the Cage, Nussbaum points to an important difference in the ethical evaluation that is involved in preparing capabilities lists: "With the human capabilities, we are
} 


\section{The Other Species Capability}

Nussbaum's list of central capabilities includes Life; Bodily Health; Bodily Integrity; Senses, Imagination, and Thought; Emotions; Practical Reason; Affiliation; Other Species; Play; and Control over One's Environment. What seems most problematic, when applied to animals, is the Other Species capability, i.e. the capability or entitlement to be able to live with concern for and in relation to animals, plants, and the world of nature (Cripps 2010, 8). This capability, Nussbaum suggests, "calls for the gradual formation of an interdependent world in which all species will enjoy cooperative and mutually supportive relations with one another. Nature is not that way and never has been. So it calls, in a very general way, for the gradual supplanting of the natural by the just" (Nussbaum 2006, 399). Due to the inclusion of the Other Species capability in her list of central capabilities, Nussbaum's solution to the predation problem is highly ambivalent.

Like most animal ethicists, Nussbaum attaches moral weight to the possibility for animals to enjoy sovereignty. She supports "the idea that species autonomy is part of the good for nonhuman animals" (id., 375). So at first glance, she seems to endorse the view that animals can pursue their own flourishing best when left to their own devices, and that we have no positive duties to support their welfare, providing them with food, shelter and healthcare. Such a "benevolent despotism" of humans over animals might even be perceived as morally repugnant, because part of what it is to flourish for animals "is to settle certain very important matters on its own, without human intervention, even of a benevolent sort" (id., 373).

On closer inspection, however, Nussbaum does not fully accept the view that we have no positive duties towards animals in the wild. The reason is that in today's world it is hardly the case anymore for animals to live sovereign and autonomous lives, unaffected by human interference. The environments on which animals depend for their survival are being increasingly disturbed or destroyed by human activity, and their opportunities for nutrition, shelter, and free movement are in constant decline. Under these human-caused conditions of deprivation, Nussbaum believes that we have a much greater moral responsibility to assist wild animals' flourishing than may at first appear.

But if non-intervention is not a plausible option, the question arises what measures should be taken to assist animals in the wild. More specifically, Nussbaum asks, "Should humans police the animal world, protecting vulnerable animals from predators?" (id., 379) This seems absurd, Nussbaum contends, should it imply that all vulnerable animals or, alternatively, all predators were to be put in "protective detention", because this would surely do more harm than good. But, like Peter Singer, Nussbaum believes that we should protect prey animals from predation if we can do so without such massive, harm-producing interventions.

Footnote 9 continued

evaluating ourselves. If we get it wrong, we are the ones who take the consequences. With animals, we are again the ones performing the evaluation-and there is great danger that we will get it wrong" (Nussbaum 2001, 1542/3). 
Another important question raised by Nussbaum concerns the introduction of 'natural predators' to control animal populations. As an example, she mentions the case of the introduction of wolfs to control an overpopulation of elks, something that took place in Yellow Stone in $1995 .{ }^{10}$ Nussbaum is opposed to such introductions of predators. She prefers any non-violent method of population control to such a violent method. The "painless predation" of animals through human hunting, she argues, may be an alternative to "other deaths that elks would die, such as starving or being torn apart by wolves" (Nussbaum 2006, 394). In an interview with Carla Faralli, Nussbaum puts it this way:

Sometimes people think that they have done a great good thing if they make hunting illegal and then, when the deer are reproducing too rapidly and can't find enough to eat, they introduce wolves to tear the deer apart. Actually, I am sure that for the deer the hunter's gun is better than the wolves' jaws, more sudden and less excruciating (Nussbaum and Faralli 2007, 158)

\section{Broadening the Capabilities Approach}

Nussbaum's aversion to predation is rooted in her vision of nature. She warns for the danger "of romanticizing nature, or suggesting that things are in order as they are, if only we humans should stop interfering" (Nussbaum 2006, 367). But she runs the risk of falling into the other extreme, by demonizing nature. ${ }^{11}$ Following John Stuart Mill in his essay Nature, she portrays predators as vicious criminals, merciless executioners and great monsters, inflicting painful torture and gruesome death on other vulnerable and defenseless creatures. Consequently, Nussbaum maintains that the harm-causing capabilities of predators "are not among those that should be protected by political and social principles" (id., 369). And she also seems to ignore or seriously underestimate the prey animal's natural abilities to evade predators. So, contrary to our initial expectation, Nussbaum's capabilities approach seems far from offering the prospect of a more balanced view of the predator-prey relationship.

However, Nussbaum's version of the capabilities approach is not uncontested; some authors, such as Breena Holland and David Schlosberg, have proposed to reshape this version because it suffers from a too narrow view of the capabilities necessary for the nonhuman world to function and flourish. Although Nussbaum's approach, by contrast to most other approaches to animal ethics, does attach ethical and political significance to species membership as such, it nonetheless adheres to a liberal individualist framework. Schlosberg notably has argued that the capabilities approach should be broadened to include not only individual animals but also entire species and ecosystems. Such broadening allows us to evaluate the predation

\footnotetext{
${ }^{10}$ With the return of the wolf the elk herd, one of the world's largest elk herds, declined $40 \%$ in 5 years. The wolves prevented elk from overbrowsing willow and aspen near rivers and streams, and this gave rise to a substantial rebound of the beaver, a keystone species that may increase species diversity et cetera. Recently, some doubts have been raised regarding this success story (Mech 2012).

11 Val Plumwood, who has profoundly reflected on the meaning of her experience of being crocodile prey after surviving a crocodile attack in February 1985 in Australia's Kakadu National Park, more or less mockingly remarked that "Predation is often demonised as bringing unnecessary pain and suffering to an otherwise peaceful vegan world of female gathering" (Plumwood 2012, 84).
} 
problem in a wide ecological context. It sheds new light on the question what it means to flourish as a prey animal: "We need to understand and accept that part of the flourishing of animals is to be the protein for other life forms...To be food for others is the essence of functioning for some beings" (Schlosberg 2007, 151).

Elizabeth Cripps has questioned whether Schlosberg's solution of the predator problem is convincing. Because, even if prey animals as a species benefit from performing the function to be food for other species, it is far from obvious that individual prey animals themselves will flourish when killed for food. To say that it is part of an individual prey animal to be food for another species, "overlooks precisely the concern for the capacity of individual animal lives to go better or worse that Nussbaum wants to recognize" (Cripps 2010, 10; cf. Hailwood 2012).

Cripps suggests that it might be possible to reinvigorate Schlosberg's attempt to make flourishing as a species, which often requires predation, compatible with flourishing as an individual by introducing the notion of 'risk'. As an example to illustrate what she means, Cripps refers to a proposal by a group of scientists to introduce the Old World cheetah as ecological replacement for the extinct American cheetah. This cat has played a crucial role in shaping the astounding speed of the pronghorn antelope, among other traits such as visual acuity. In the absence of this predator, "the pronghorn appears overbuilt today in precisely those traits that make it so distinctive among North American mammals, raising the question of whether a reconstitution of Pleistocene selective pressures warrants consideration" (Donlan et al. 2006, 662). According to Cripps, this could indicate that, due to lack of cheetahs, the pronghorn cannot flourish fully because it has no incentive to make full use of its remarkable abilities. "Thus, quite apart from the benefit to the species, it might be in the individual pronghorn's interest to run a risk of being killed by a cheetah" (Cripps 2010, 17).

As we will see in the next section, with this suggestion Cripps anticipates, as it were, the solution to the predation problem that Sue Donaldson and Will Kymlicka have presented in their seminal 2011 book Zoopolis.

\section{Political Theory of Animal Rights}

Donaldson and Kymlicka have developed their political theory of animal rights as an alternative to the traditional animal rights theory. Due to its one-sided focus on the intrinsic moral status or standing of animals as the sole basis of our moral obligations towards them, the traditional animal rights theory seems unable to resolve a wide range of pressing issues regarding human-animal interactions, and is thereby at least partly to blame for what Donaldson and Kymlicka perceive as the political and intellectual impasse of the animal advocacy movement. To overcome this impasse, they have made an attempt to shift the debate from the field of moral theory to the field of political theory, focusing on the differential obligations that arise from the varied ways that animals are related to human societies and institutions.

In Zoopolis, Donaldson and Kymlicka draw upon the concepts and categories of political theory to illuminate the specific rights and responsibilities we have in our 
various relationships with animals. They distinguish three types of morally significant human-animal relationships: domesticated animals, such as companion animals and farm animals, should be considered and treated as our co-citizens; wild animals should be recognized as members of separate, sovereign nations, entitled to protection from infringements of their right to self-determination; and, lastly, "liminal" animals, i.e., non-domesticated animals such as rats and raccoons who live among humans, should be designated the status of "denizens". 12

\section{Similarities and Dissimilarities with Capabilities Approach}

Donaldson and Kymlicka concede that they are sympathetic to Nussbaum's capabilities approach, and that, at the most abstract level, their own citizenship model could be described in broadly capability terms (2011, 95; 275). Like Nussbaum, they treat animals not just as passive victims of human domination and mere objects of compassion but rather as subjects with a clear capacity for agency. And like Nussbaum, they consequently also challenge the one-sided focus of most accounts of animal ethics on negative rights- "thou shall not kill, use, or keep animals" (id., 254). It is the dominant view within animal ethics that the abolishment of animal exploitation and the liberation of animals from enslavement will ultimately rule out virtually all forms of human-animal interaction- "there should be no human-animal relations" (ibid.). According to Donaldson and Kymlicka, this narrow vision of animal rights is at the root of the impasse of the animal advocacy movement because it may discourage all efforts to find out what non-exploitative relations might look like, and what kind of positive obligations we owe to animals, be they domesticated, wild or liminal.

So there are important similarities between Nussbaum's capabilities approach and Donaldson and Kymlicka's political theory of animal rights: both consider animals as moral agents rather than as moral patients, and both aim to complement negative rights with positive rights. But there is also a distinct difference: Nussbaum attaches considerable importance to species membership, whereas Donaldson and Kymlicka focus on community membership, thus taking account of the sociopolitical context of animal justice. They acknowledge that Nussbaum's species norm of flourishing is probably a reasonable standard for animals living in the wild, but they deny that this norm makes sense with respect to domesticated and liminal animals. Another drawback of the preoccupation with species norms is lack of sensitivity to the associations between species and individual variation within species.

\section{Competence and Risk}

According to Donaldson and Kymlicka, the argument that the flourishing of wild animals would be undermined by interfering with wildlife to prevent predation is "perhaps the most important one, but also the least developed" (2011, 165). This

\footnotetext{
12 The group of liminal animals include opportunistic animals, agricultural symbiotics (or niche specialists), feral animals and introduced exotics (see Donaldson and Kymlicka 2011, 219-226).
} 
"flourishing argument", as they call it, needs qualification and clarification. Similar to Cripps' critique of Schlosberg, they argue that it is difficult to see how preventing a deer from being killed by a predator is detrimental to her flourishing. And just like Cripps they invoke the notion of 'risk' to address this question. For societies with an interest in self-determination, eliminating the risk of harm or suffering "would involve a terrible curtailment of freedom, including the freedom to fully develop and explore one's capabilities. Individual action to protect a human child at the moment of harm contributes to her flourishing; collective action to prohibit the actions or processes that create the risk of harm is likely to undermine human flourishing. So, too, with animals" (id., 166).

Donaldson and Kymlicka believe that, when it comes to the daily management of the risks of living in the wild, it is reasonable to assume that wild animals are fully competent in general to address the challenges they face: they have the skills to secure and store food, to find or construct shelter, to care for the young, to cover long distances, to hunt, and also to reduce the risk of predation. ${ }^{13}$ Because wild animals are competent to manage their own affairs, we are not obligated to systematically intervene to end predation or to control natural food cycles. Respect for the sovereignty of wild animals, in fact, rules out this kind of intervention as it would condemn wild animals to a permanent state of dependency. ${ }^{14}$

\section{Positive and Negative Duties}

It would, however, be a mistake to think that respect for sovereignty requires a complete hands-off approach with respect to animals in the wild. Donaldson and Kymlicka mention two broad categories of assistance and intervention that do not threaten but may even promote values of autonomy and self-determination: largescale interventions to prevent or mitigate natural or human-caused disasters, such as deflecting a large meteor on a collision course with a wilderness zone populated by numerous animals, or halting an aggressive new bacterium which is ready to invade and destroy an ecosystem; and small-scale or micro-scale interventions aimed to aid or rescue individual animals in distress, such as saving an animal who has fallen through the ice from drowning or releasing a beached whale to open water.

In addition to these positive duties to aid, assistance, and intervention, there are also important negative duties that derive from the respect for sovereignty we owe animals in the wild. We should never infringe on the rights to their own territory and

\footnotetext{
${ }^{13}$ Ethological and ecological research shows that prey species have gained over evolutionary time a stunning array of mechanisms to cope with predators for every stage of their struggle: the avoidance of detection by the predator (such as camouflage, refuge use, nocturnality), the avoidance of attack once detected (mimicking animals with strong defenses, signaling to the predator that pursuit is not worthwhile), the avoidance of capture once attacked (fleeing, bluffing strength), and the avoidance of consumption once captured (playing death or 'thanatosis', sacrificing body parts or 'autotomy').

14 Donaldson and Kymlicka admit that their competence argument is more compelling in relation to some animals than to others. In fact, they agree with Horta (2013) that members of r-selected species have less scope for 'competent agency' than members of K-selected species. But on balance, they believe that "we should still respect the sovereignty of wild animals, including those for whom there is minimal evidence of competent agency" (Donaldson and Kymlicka 2011, 177; cf. Donaldson and Kymlicka 2013, 154).
} 
to autonomy on that territory, which are key components of the principle of sovereignty. These rights impose, first of all, immediate and drastic restrictions on human expansion into wild animal territories and the ongoing fragmentation and destruction of wild animal habitat. They also impose stringent limits on human actions that have harmful impacts beyond the borders of wild animal territories, such as water contamination, air pollution and the various effects of climate change. To avoid such cross-border impacts we will have to reduce our ecological footprint and replace our environmentally destructive behavior and cost-externalizing practices with fair and sustainable ones.

\section{The Limits of a Place-Based Approach}

Donaldson and Kymlicka contrast their sovereignty model with the 'stewardship' model, often found in environmental science, philosophy and policy. In this model, habitat for wild animals is created in the shape of wild areas such as wildlife refuges, nature reserves, and national parks, where humans enjoy sovereign authority and exercise stewardship over wild animals. The sovereignty model, on the other hand, doesn't grant humans the right to govern wild animal territory, but is based on the principle that sovereign entities are entitled to the same or similar claims to authority, and should deal with each other on an equal footing. This means that when we humans enter wild animal territory, "we do so not in the role of stewards and managers, but as visitors to foreign lands" (id., 170).

Both models, however, have one thing in common-like the classical stewardship model, the sovereignty model has taken a place-based approach with regard to wild animals. Donaldson and Kymlicka argue for an immediate check on the expansion of human settlement, for giving wild animals back control over their own territories, for returning vast areas of land currently devoted to animal agriculture to wild animals, for re-establishing wildlife corridors and migration routes et cetera. But such a place-based approach seems to fall far short of what presently is really required to maintain or restore wild animals' autonomy (Sandler 2012).

Hitherto, place-based or in situ conservation is usually given priority over 'out of place' or ex situ conservation. The latter is considered to be justified only as a supportive measure to the former. This hierarchical understanding of the relationship between in situ and ex situ conservation reflects the importance of the place of origin-'wild nature' (Braverman 2015, 33). This understanding is however increasingly being called into question given today's ecological challenges that can be summarized under the denominator of the 'Anthropocene', the current geological epoch in which human activities are so profound and pervasive that humanity itself has emerged as a global geophysical force, at least as important as natural forces (Keulartz and Bovenkerk 2016).

\section{Blurring Boundaries}

Under Anthropocenic conditions many wild populations are no longer viable on their own. Mainly due to habitat fragmentation and habitat loss, there is an ongoing conversion of what originally were continuous populations to so-called 
'metapopulations': collections of subpopulations, that are spread geographically over patches of habitat. Because these patches are usually small and because the movement of the animals between these patches is restricted for lack of connectivity, an increasing number of subpopulations are declining and are teetering on the edge of extinction. In this situation ex situ conservation has a more prominent role to play and is now regarded as equivalent, rather than subordinate to in situ conservation.

Because it is no longer considered effective to manage wild and captive populations in isolation from one another, practitioners of species conservation therefore increasingly use the so-called One Plan Approach that was officially proposed to the IUCN World Conservation Congress in 2012. The One Plan Approach promotes the interactive exchange of animals between in situ populations (in the wild) and ex situ populations (in captivity) for mutual reinforcement, a management approach that is also referred to as inter situ conservation (Braverman 2014) or pan situ conservation (Minteer and Collins 2013). With animals moving in both directions, the stability and sustainability of wild and captive populations can be greatly enhanced. On the one hand, captive populations can be used for restocking in areas with declining populations or for reintroduction in areas where populations have gone extinct; on the other hand, the demographic and genetic viability of ex situ populations can be boosted by supplying genetic founders from wildlife populations (Byers et al. 2013).

With the One Plan Approach captive populations can be used for the conservation of in situ populations on the brink of extinction as a result of habitat fragmentation. But what if in situ conservation itself is being undermined by that other major environmental stressor-rapid global climate change-, that makes the species' historic indigenous ranges increasingly inhospitable? And when, moreover, populations are not able to move on their own to other areas with more suitable environmental conditions? A conservation measure that may prevent species that are unable to keep pace with rapid climate change from going extinct is assisted migration or assisted colonization, i.e. the intentional movement of 'climate refugees' to new habitats outside their historical range, which they otherwise could not reach (Hoegh-Guldberg et al. 2008). Whereas inter or pan situ conservation involves the movement of animals from one location to another within the species' indigenous range, assisted migration or colonization relates to animal translocations outside the species' indigenous range. ${ }^{15}$

The emergence of these new conservation strategies makes it clear that the distinction between classic in situ (on-site) and ex situ (off-site) conservation is becoming blurred to the point of disappearing entirely. We witness what Braverman $(2015,15)$ has called a shift "from bifurcation to amalgamation" of in situ and ex situ conservation: the increased development of hybrid approaches, that integrate the wild and the captive. (Pritchard et al. 2011; Redford et al. 2012, 2013; Minteer et al. 2016).

\footnotetext{
15 "The indigenous range of a species is the known or inferred distribution generated from historical (written or verbal) records, or physical evidence of the species' occurrence" (IUNC/SSC 2013, 2).
} 
It is clear that with the ongoing blurring of the boundaries between in situ and ex situ conservation, placed-based models such as the classic stewardship model but also Donaldson and Kymlicka's sovereignty model, are increasingly rendered meaningless. Under Anthropocenic conditions positive interventions can no longer be limited to providing assistance in the event of natural or human-caused disasters, or to micro-level individual acts of compassion only. Apart from these isolated, incidental cases, Donaldson and Kymlicka believe that we should leave nature to its own devices - "in general, a hands-off principle towards wild animals is a sound one" $(2011,185)$. But that ship seems to have sailed already. ${ }^{16}$ Ironically or not, but today we are morally obligated to systematically interfere with wildlife, not to prevent predation, as utilitarians in particular would have it, but to assist endangered species in maintaining and improving their competences to survive on their own in the wild, including the skills to hunt and to avoid predators, something which is already taking place on the ground.

\section{Learning to Hunt and to Avoid Predators}

Especially zoo-based expertise in sustaining small but demographically and genetically sound populations of captive animals has been proven useful for the conservation of small and declining populations in the wild. Zoo-based skills in animal handling may, moreover, be helpful at many of the main stages of animal translocations, from capture, transport, and captive breeding, to pre-release training (Fa et al. 2011, 210). The later is particularly important because captive animals may lack the behavioral competences needed for survival in the wild, and may thus compromise the ability of captive populations to contribute to the recovery of wild populations. Pre-release training is aimed at maintaining or developing the skills that may have been lost in captivity such as orientation and navigation, finding or building suitable nest sites, hunting and foraging behavior, and predator avoidance (Earnhardt 2010; McPhee and Carlstead 2010).

Predator avoidance training is vital to the success of conservation efforts that rely on captive animals because a substantial number of post-release deaths are due to predators. It usually consists of exposure to live predators or to predator models paired with some aversive or stressful stimulus such as an alarm signal. Given that many animals are so-called 'mesopredators', i.e. animals which both predate and are predated upon, antipredator training has often to be combined with developing predatory skills. A case in point is the black-footed ferret.

In 1986, the population of ferrets had diminished to a mere 18 individuals, but thanks to a captive breeding program, between 500 and 800 now roam the prairie of the US state of Wyoming. The program was not, however, entirely plain sailing. When the kits were released they were far too blasé to make themselves scarce when predators such as eagles, coyotes and badgers arrived on the scene. The

\footnotetext{
${ }^{16}$ Donaldson and Kymlicka grossly underestimate the impact of anthropogenic environmental change, that currently takes place at such a fast speed and large scale that it definitely poses a threat to the resilience of the Earth System (Steffen et al. 2007, 2011). They denounce the "fashionable talk" of the Anthropocene, that has had "the perverse effect of making continued human encroachment on, and management of, wild animal habitat seem inevitable" (Donaldson and Kymlicka 2016).
} 
researchers tried to resolve this problem by building a mock predator. They attached wheels to a stuffed badger, which would win fame as RoboBadger. The only way the ferrets could escape RoboBadger was to find a burrow. The researchers then tried to increase the ferrets' aversion to RoboBadger by firing rubber bands at them. (McCarthy 2004, 196/7). ${ }^{17}$

But the ferrets have not only to learn how to avoid predators, but also how to locate and kill prairie dogs which make up between 65 to 90 percent of their diet. In addition, they have to learn how to invade and inhabit prairie dogs burrows because they do not build their own burrows. Their preconditioning period lasts for 30 days. During that time the ferrets ideally kill four prairie dogs and live in an actual prairie dog burrow system. The survival rate of these animals is about ten times higher than animals released straight out of the cage (Braverman 2015, 119-123). ${ }^{18}$

\section{Concluding Remarks}

Donaldson and Kymlicka rightly argue that wild animals are fully competent to manage their own affairs, and that we therefore should refrain from protecting prey animals against predation. Without predation, prey animal's possibilities for flourishing will be diminished, because all the amazing capabilities they have gained over evolutionary time to cope with predators might be rendered meaningless. All in all, we can safely conclude that it is counterproductive to extent Nussbaum's Other Species capability to the animal kingdom. Instead of working to ensure that all species will enjoy cooperative and mutually supportive relations, we should respect the natural capabilities of animals, be they predator or prey, without romanticizing or demonizing their agonistic interactions.

But their place-based sovereignty model is inadequate in the light of what has been called the planet's 'sixth mass extinction'. Unlike earlier mass extinctions, the current one is not primarily driven by natural events such as meteorite impacts or volcanic eruptions but by the effects of the activities of Homo sapiens. Especially human-caused rapid climate change together with habitat conversion, fragmentation, and destruction have led to a global wave of species and population extirpations and declines in local species abundance. ${ }^{19}$

If we really want to stop or even reverse this so-called 'defaunation' process we can no longer hold on to the idea that species conservation can be accomplished with minimal management by establishing large nature reserves and by creating connections such as corridors and stepping stones between them. Preserving the ecological status quo through such traditional measures increasingly resembles a

\footnotetext{
17 This was, by the way, not a great success as became clear when the ferrets started riding on the back of RoboBadger.

18 See also http://video.nationalgeographic.com/video/news/150407-black-footed-ferret-hunting-realityvin.

19 Surprisingly enough, nowhere in Zoopolis do Donaldson and Kymlicka even mention the staggering decline in species numbers; they use the notion of 'extinction' only in relation to those proposals from animal rights theorists who call for a complete end to domestication and the extinction of domesticated species.
} 
Sisyphean task. In situ conservation (in the wild) is no longer effective without ex situ conservation (in zoos and aquariums).

Donaldson and Kymlicka condemn capturing animals and putting them in zoos, even in the most progressive zoos, as "a violation of their basic individual rights, and a violation of their rights as members of sovereign communities" (2011, 283; cf. 293). Such condemnation only shows how blind they are to the important role that zoos and other ex situ institutions have to play under current conditions of anthropogenic stress (see Keulartz 2016b).

Open Access This article is distributed under the terms of the Creative Commons Attribution 4.0 International License (http://creativecommons.org/licenses/by/4.0/), which permits unrestricted use, distribution, and reproduction in any medium, provided you give appropriate credit to the original author(s) and the source, provide a link to the Creative Commons license, and indicate if changes were made.

\section{References}

Braverman, I. (2014). Captive for life: Conserving exptinct in the wild species through ex situ breeding. In L. Gruen (Ed.), The ethics of captivity (pp. 193-212). Oxford: Oxford University Press.

Braverman, I. (2015). Wild life. The institution of nature. Stanford, CA: Stanford University Press.

Byers, O., Lees, C., Wilcken, J., \& Schwitzer, C. (2013). The one plan approach: The philosophy and implementattion of CBSG's approach to integrated species conservation planning. WAZA Magazine, $14,2-5$.

Clark, S. R. L. (1979). The rights of wild things. Inquiry, 22(1-4), 171-188.

Cohen, C. (1997). Do animals have rights? Ethics and Behavior, 7(2), 91-102.

Cowen, T. (2003). Policing nature. Environmental Ethics, 25(2), 169-182.

Cripps, E. (2010). Saving the polar bear, saving the world: can the capabilities approach do justice to humans, animals and ecosystems? Res Publica, 16, 1-22.

Dawrst, A. (2009). The predominance of wild-animal suffering over happiness: An open problem. Essays on Reducing Suffering. http://reducing-suffering.org/wp-content/uploads/2015/02/wild-animals_ 2015-02-28.pdf

Donaldson, S., \& Kymlicka, W. (2011). Zoopolis. A political theory of animal rights. Oxford, NY: Oxford University Press.

Donaldson, S., \& Kymlicka, W. (2013). A defense of animal citizens and sovereigns. LEAP: Laws Ethics and Philosophy, 1, 143-160.

Donaldson, S., \& Kymlicka, W. (2016). Between wildness and domestication: Rethinking categories and boundaries in response to animal agency. In B. Bovenkerk, \& J. Keulartz (Eds.), Animal ethics in the age of humans. Dordrecht: Springer.

Donlan, J., et al. (2006). Pleistocene rewilding: An optimistic agenda for twenty-first century conservation. The American Naturalist, 168, 160-183.

Dorado, D. (2015). Ethical interventions in the wild. An annotated Bibliography. Relations. Beyond Anthropocentrism, 3(2), 219-238.

Earnhardt, J. M. (2010). The role of captive populations in reintroduction programs. In D. G. Kleiman, K. V. Thompson, \& C. K. Baer (Eds.), Wild mammals in captivity (pp. 263-267). Chicago: The University of Chicago Press.

Fa, J., Funk, S., \& O'Connell, D. (2011). Zoo conservation biology. Cambridge: Cambridge University Press.

Fink, Ch. (2005). The predation argument. Between the Species, 13(5), 1-15.

Hadley, J. (2006). The duty to aid nonhuman animals in dire need. Journal of Applied Philosophy, 23(4), 445-451.

Hailwood, S. (2012). Bewildering Nussbaum: Capability justice and predation. The Journal of Political Philosophy, 20(3), 293-313.

Hoegh-Guldberg, O., Hughes, L., McIntyre, S., Lindenmayer, D. B., et al. (2008). Assisted colonization and rapid climate change. Science, 321(5887), 345-346. 
Horta, O. (2010a). Debunking the idyllic view of natural processes: Population dynamics and suffering in the wild. Télos, 17(1), 73-88.

Horta, O. (2010b). The ethics of the ecology of fear against the nonspeciesist paradigm: A shift in the aims of intervention in nature. Between the Species, 13(10), 163-187.

Horta, O. (2013). Zoopolis, intervention, and the state of nature. LEAP: Laws Ethics and Philosophy, 1, $113-125$.

IUCN/SSC. (2013). Guidelines for reintroductions and other conservation translocations. Version 1.0. Gland: IUCN Species Survival Commission.

Jamieson, D. (1990). Rights, justice, and duties to provide assistance: A critique of Regan's theory of rights. Ethics, 100, 349-362.

Jamieson, D. (2008). The rights of animals and the demands of nature. Environmental Values, 17, $181-199$.

Keulartz, J. (2016a). Towards an animal ethics for the Anthropocene. In B. Bovenkerk \& J. Keulartz (Eds.), Animal ethics in the age of humans. Dordrecht: Springer.

Keulartz, J. (2016b). Ethics of the zoo. Oxford Research Encyclopedia of Environmental Science.

Keulartz, J., \& Bovenkerk, B. (2016). Changing relationships with non-human animals in the Anthropocene. In B. Bovenkerk \& J. Keulartz (Eds.), Animal ethics in the age of humans. Dordrecht: Springer.

McCarthy, S. (2004). Becoming a tiger. How baby animals learn to live in the wild. New York: Harper Perennial.

McMahan, J. (2010). The meat eaters. The New York Times, September 19, 2010.

McPhee, M. E., \& Carlstead, K. (2010). The importance of maintaining behaviours in captive mammals. In D. G. Kleiman, K. V. Thompson, \& C. K. Baer (Eds.), Wild mammals in captivity (pp. 303-313). Chicago: The University of Chicago Press.

Mech, L. D. (2012). Is science in danger of sanctifying the wolf? Biological Conservation, 150, $143-149$.

Milburn, J. (2015). Rabbits, Stoats and the predator problem: Why a strong animal rights position need not call for human intervention to protect prey from predators. Res Publica, 21(3), 273-289.

Minteer, B., \& Collins, J. (2013). Ecological ethics in captivity: Balancing values and responsibilities in zoo and aquarium research under rapid global change. ILAR, 54(1), 41-51.

Minteer, B., Collins, J., \& Raschke, A. (2016). Between the wild and the walled: The evolution and ethics of zoo conservation. In B. Hale \& A. Light (Eds.) Routledge companion to environmental ethics (forthcoming).

Ng, Y.-K. (1995). Towards welfare biology: Evolutionary economics of animal consciousness and suffering. Biology and Philosophy, 10(4), 255-285.

Nussbaum, M. C. (2000). Women and human development: The capabilities approach. Cambridge: Cambridge University Press.

Nussbaum, M. C. (2001). Animal rights: the need for a theoretical basis. Harvard Law Review, 114, $1506-1549$.

Nussbaum, M. C. (2006). Frontiers of justice. Disability, nationality, species membership. Cambridge, MA: Havard University Press.

Nussbaum, M. C., \& Faralli, C. (2007). On the New frontiers of justice. A dialogue. Ratio Juris, 20(2), $145-161$.

Palmer, C. (2010). Animal ethics in context. New York: Columbia University Press.

Palmer, C. (2015). Against the view that we are normally required to assist wild animals. Relations, 3(2), 203-210.

Pearce, D. (1995). The hedonistic imperative. http://www.hedweb.com/hedethic/tabconhi.htm. Accessed May 2016.

Pearce, D. (2009). Reprogramming predators. http://www.hedweb.com/abolitionist-project/ reprogramming-predators.html

Plumwood, V. (2012). The eye of the crocodile (L. Shannon, Ed.). Canberra: ANU E Press.

Pritchard, D., Fa, J., Oldfield, S., \& Harrop, S. (2011). Bring captive closer to the wild: Redefining the role of ex situ conservation. Oryx, 46(1), 18-23.

Rachels, J. (1990). Created from animals: The moral implications of Darwinism. New York: Oxford University Press.

Redford, K., Jensen, D., \& Breheny, J. (2012). Integrating the captive and the wild. Science, 338, 1157-1158.

Redford, K., Jensen, D., \& Breheny, J. (2013). The long overdue death of the ex situ and in situ dichotomy in species conservation. WAZA Magazine, 14, 19-22. 
Regan, T. (1983). The case for animal rights. Berkeley, CA: University of California Press.

Regan, T. (2001). The case for animal rights: A decade's passing. In T. Regan (Ed.), Defending animal rights (pp. 39-65). Champaign: University of Illinois Press.

Regan, T. (2004). The case for animal rights (2nd ed.). Berkeley, CA: University of California Press.

Ritchie, D. G. (2002). Natural rights. A criticism of some political and ethical concepts. London: Routledge.

Sagoff, M. (1984). Animal liberation and environmental ethics: Bad marriage, quick divorce. Osgoode Hall Law Journal, 22(2), 297-307.

Sandler, R. L. (2012). The ethics of species. An introduction. Cambridge: Cambridge University Press.

Sapontzis, Steve F. (1984). Predation. Ethics and animals, 5(2), 27-38.

Schlosberg, D. (2007). Defining environmental justice: Theories, movements, and nature. New York: Oxford University Press.

Simmons, A. (2009). Animals, predators, the right to life and the duty to save lives. Ethics and the Environment, 14, 15-27.

Singer, P. (1973). Food for thought, reply to David Rosinger. New York Review of Books, June 14. http:// www.nybooks.com/articles/1973/06/14/food-for-thought/. Accessed May 2016.

Singer, P. (1975). Animal liberation. New York: Random House.

Steffen, W., Crutzen, P. J., \& McNeill, J. R. (2007). The anthropocene: Are humans now overwhelming the great forces of nature? Ambio, 36(8), 614-621.

Steffen, W., et al. (2011). The anthropocene: From global change to planetary stewardship. Ambio, 40(7), 739-761.

Tomasik, B. (2015). The importance of wild-animal suffering. Relations. Beyond Anthropocentrism, 3(2), $133-152$. 